\title{
Effect of Biofermentation with Taxifolin on Physicochemical and Microbiological Properties of Cold-Smoked Pork Sausages
}

\author{
Sonata Gustiene ${ }^{1 *} \odot$, Gintare \\ Zaborskiene ${ }^{1,2} \oplus$, Anita \\ Rokaityte $\bullet$ and Reda \\ Riešute ${ }^{2}$ ○(

\begin{abstract}
'Department of Food Safety and Quality, Lithuanian University of Health Sciences, Veterinary Academy, Tilzes St. 18, Kaunas, LT-47181 Lithuania

${ }^{2}$ Food Institute, Kaunas University of Technology, Radvilenu St. 19, Kaunas, LT-51180 Lithuania
\end{abstract}

Received: 14 February 2019 Accepted: 15 November 2019

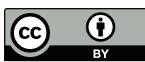

\begin{abstract}
SUMMARY
The aim of this work is to evaluate the effect of taxifolin on the physicochemical and microbiological properties of cold-smoked pork sausages produced using different commercial starter cultures with Leuconostoc carnosum and with a mixture of Pediococcus pentosaceus and Staphylococcus xylosus. Ultra performance liquid chromatography analysis demonstrated that after 181 days of storage total taxifolin content was the highest in samples with taxifolin and L. carnosum (60\%), compared to the first day of storage. The sausages with taxifolin and the mixture of P. pentosaceus and S. xylosus (56\%) followed next. Taxifolin improved the hygienic quality of sausages without significant effect on the growth of lactic acid bacteria. The accumulation of biogenic amines, including histamine and putrescine, was more effectively reduced in sausages inoculated with the taxifolin and P. pentosaceus and S. xylosus mixture. Using this mixture, the rate of lipolysis and lipid oxidation were effectively slowed down. Samples with taxifolin and L. carnosum showed the highest free radical scavenging activity on the first day of the study ((77.4 \pm 1.3$) \%)$ ( $p<0.05$ in all samples). Mixtures containing taxifolin and starter cultures bound free radicals better than taxifolin alone. The colour parameters $\left(L^{*}, a^{*}\right.$ and $\left.b^{*}\right)$ of preparations and final products were significantly influenced by taxifolin and starter cultures and storage time $(p<0.05$ in all samples).
\end{abstract}

Key words: Leuconostoc carnosum, Pediococcus pentosaceus, Staphylococcus xylosus, biogenic amines

\section{INTRODUCTION}

The application of bioflavonoids as natural antioxidants for treatment of cold-smoked pork sausages produced using commercial starter cultures has not been discussed in the available literature. Taxifolin (also known as 3,5,7,3',4'-pentahydroxy-flavanone or 2,3-dihydroquercetin) is a member of the group of flavanones (1). The satisfactorily pure taxifolin may be extracted from Siberian larch (Larix sibirica Ledeb.) and is also abundant in citrus fruits, grapes, olive oil and onions (2,3). As a common bioactive constituent of foods and herbs, taxifolin has been shown to exert a wide range of positive biochemical and pharmacological effects on human health. As a typical flavonoid, it inhibits free radical formation (4), influences the physical properties of lipids in biological membranes (5), has anti-inflammatory and analgesic properties (6), as well as cardioprotective and neuroprotective effects $(7,8)$.

Taxifolin has many health-promoting effects, but is unstable under the light, with $\mathrm{pH}$ changes and during thermal treatment (9-11). Besides, little is known about the degradation behaviour of taxifolin during storage. Knowledge about the stability of taxifolin in food processing is important in order to predict the duration of physiological effects in food and beverages (12). European Regulation (EC) No 1129/2011 (13) reports the food additives authorized for use in Europe and their maximum permitted levels. On 13 December 2016, the EFSA NDA Panel adopted the Scientific Opinion on the safety of taxifolin as a novel food ingredient in non-alcoholic beverages, yoghurts, chocolate confectionery and food supplements pursuant to Regulation (EC) No 2015/2283 (14). The maximum 
proposed amounts of taxifolin are $0.02 \mathrm{~g} / \mathrm{L}$ in non-alcoholic beverages, $0.02 \mathrm{~g} / \mathrm{kg}$ in yoghurts and $0.07 \mathrm{~g} / \mathrm{kg}$ in chocolate confectionery. The maximum proposed daily intake of taxifolin from food supplements is $100 \mathrm{mg} /$ day (15). Scientific literature indicates the most suitable amount of taxifolin in meat products to be between 0.006 and $0.04 \%$, depending on the fat content (16).

In the future, taxifolin could be used as a natural antioxidant and antimicrobial additive in the food industry (17), e.g. in cold-smoked fermented sausages with starter cultures due to the fact that taxifolin has been described as having antimicrobial (18) and radical scavenging activity (19), and a protective role in plants against pathogens (20). The addition of selected starter cultures has been reported to improve the safety of fermented sausages by restraining the development of undesired microorganisms, thus reducing the risk of pathogenic and spoilage bacteria, maintaining stability and shelf life, and enhancing the sensory characteristics of the meat products (21).

The aim of this work is to evaluate the effect of mixtures of taxifolin and different commercial starter cultures on physicochemical and microbiological properties of cold-smoked pork sausages in order to select the most suitable mixture regarding the safety and quality of sausages during storage.

\section{MATERIALS AND METHODS}

\section{Preparation of taxifolin solution}

Taxifolin ( $\geq 85 \%$ ) was obtained from Sigma-Aldrich $\mathrm{GmbH}$, Merck (Buchs, Switzerland). It was dissolved in several drops of ethanol (96\%), diluted with double distilled water and added to the minced pork $(0.517 \mathrm{mg} / \mathrm{kg})$.

\section{Sausage production and sampling procedures}

Eight different batches of pork sausages were manufactured using different techniques: three batches with the addition of different starter cultures in a proportion defined by the manufacturer (Chr. Hansen, Roskilde, Denmark), three batches with the addition of starter cultures and taxifolin, one batch with only taxifolin and one control batch without starter culture or taxifolin. The batches were prepared as follows: CR-1 with Leuconostoc carnosum starter culture, CR-2 with Pediococcus pentosaceus and Staphylococcus xylosus, CR-3 with P. pentosaceus in high quantity and S. xylosus, CR-4 with taxifolin and L. carnosum, CR-5 with taxifolin, P. pentosaceus and S. xylosus, CR-6 with taxifolin, P. pentosaceus in high quantity and S. xylosus, CR-7 with only taxifolin, and CR-8 (control) without taxifolin or starter culture.

The composition of pork sausages was as follows: whole pork muscle and back fat cuttings ( $80 \%$ ) and raw pork ham (20\%), purchased from a local butcher's in Kedainiai, Lithuania, with the addition of the following ingredients (in $\mathrm{g} / \mathrm{kg}$ ): sodium chloride 25 , lactose 20 , dextrin 20 , sodium caseinate 20 , glucose 7 , black pepper 1.5, white pepper 1 and sodium ascorbate 0.5, all purchased from Sauda, Garliava, Lithuania. The whole muscle cuts and raw ham were minced by electric meat grinder (Bosch MFW68660; Frankfurt, Germany) through a 13-mm diameter mincing plate and mixed together with the other ingredients for $3 \mathrm{~min}$. The mixture was kept at $4{ }^{\circ} \mathrm{C}$ for $24 \mathrm{~h}$ in a refrigerator (Snaige FR240-1101AA; Kaunas, Lithuania) and then stuffed into natural casings with a diameter of 45 $\mathrm{mm}$ and a length of $9 \mathrm{~cm}$. Thin cold smoke was applied (Helia Smoker, Burbach, Germany) over a period of $24 \mathrm{~h}$ until the casings developed yellow to light brown colour. The sausages were fermented for 2 days at $15^{\circ} \mathrm{C}$ and $85 \%$ relative humidity, then transferred into a ripening chamber where they were kept for 18 days at $10-12{ }^{\circ} \mathrm{C}$ and $75-80 \%$ relative humidity until the yield was $87 \%$ compared to the original meat mass. The cold-smoked sausages were then kept for 181 days at $15{ }^{\circ} \mathrm{C}$ and $75 \%$ relative humidity. Taxifolin stability, physicochemical properties and microbiological profile of sausages were analysed after 1,33, 128 and 181 days of storage. The analyses were carried out in triplicates, and experiments were repeated twice.

\section{Determination of taxifolin in cold-smoked sausages using ultra performance liquid chromatography}

All the reagents and standards of analytical grade, HPLC-grade acetonitrile, trifluoroacetic acid and taxifolin were from Sigma-Aldrich GmbH, Merck (Buchs, Switzerland). Deionized water was acquired from a Milli-Q purification system (Millipore Corporation, Bedford, MA, USA).

Sausage samples $(1 \mathrm{~g})$ were transferred into a $100-\mathrm{mL}$ stoppered conical flask. Ethanol $(96 \%, 100 \mathrm{~mL})$ was added, and placed on a rotary shaker (Thermo Scientific MaxQ 4000 shaker; Thermo Fisher Scientific, Waltham, MA, USA) under agitation (300 rpm) for $30 \mathrm{~min}$, then the mixture was filtered through filter paper (grade $601 \mathrm{~A}$; Whatman, Maidstone, UK). The clear portion was kept in a freezer (Snaigè FR240-1101AA) for at least $20 \mathrm{~min}$ for the extraction of fat. The mixture was then centrifuged at $7500 \times \mathrm{g}$ for $20 \mathrm{~min}$ at $4{ }^{\circ} \mathrm{C}$ (TJ-6 refrigerated centrifuge; Beckman Coulter, Palo Alto, CA, USA). The upper phase was filtered through a $0.2-\mu \mathrm{m}$ pore-size syringe filter (Acrodisc LC13 PVDF; Sigma-Aldrich, Merck, Oakville, ON, Canada) and injected into the HPLC unit.

Ultra performance liquid chromatography (UPLC) was carried out with a Waters ACQUITY UPLC ${ }^{\circledR}$ system consisting of binary solvent manager, auto sampler, column manager, and photometric diode array detector (Milford, MA, USA). The UPLC column was a $2.1 \mathrm{~mm} \times 100.0 \mathrm{~mm}$ Acquity UPLC BEH C18 (Waters) with $1.7 \mu \mathrm{m}$ particles. The mobile phase consisted of $0.1 \%$ taxifolin in deionized water (A) and acetonitrile (B). The gradient was formed as follows: initially, the separation was started with $88 \% \mathrm{~A}$ and held for $1 \mathrm{~min}$, then in $3 \mathrm{~min} \mathrm{~A}$ was decreased to $70 \%$, after that within 3 min to $10 \%$, and finally held at $10 \%$ for $1 \mathrm{~min}$. Then the column was allowed to equilibrate for $2 \mathrm{~min}$. The flow rate was $0.5 \mathrm{~mL} / \mathrm{min}$, and the injection volume was $1 \mu \mathrm{L}$. The detector was set in the 200$400 \mathrm{~nm}$ range. The chromatographic data were acquired and processed with Empower 3 software (22). 


\section{Chemical analyses}

The moisture content of cold-smoked pork sausage samples was determined according to ISO 1442:2000 (23). Approximately $1.0 \mathrm{~g}$ of sample was weighed in a moisture dish covered with a lid and the mass was recorded. The dish was then uncovered and placed in the oven (Universal Mechanical Oven UF 110 Plus; Memmert Frankfurt, Germany) at (102 \pm 2$)$ ${ }^{\circ} \mathrm{C}$ for $2 \mathrm{~h}$ along with the lid. After drying, the dish was again covered with the lid and transferred to the desiccator to cool to room temperature. Then, it was carefully weighed and the process was repeated until the mass did not differ by more than $0.5 \mathrm{mg}$ between measurements. Moisture content was then calculated from the following formula:

$$
w(\text { moisture })=\frac{m_{1}-m_{2}}{m_{1}-m_{0}} \cdot 100
$$

where $m_{0}$ is the mass (in $\mathrm{g}$ ) of the dish, rod and sand, $m_{1}$ is the mass (in $\mathrm{g}$ ) of the dish containing the test portion, rod and sand before drying, and $m_{2}$ is the mass (in g) of the dish containing the test portion, rod and sand after drying.

The $\mathrm{pH}$ of sausages was measured according to the standard method ISO 2917:2002 (24) using a PP-15 professional pH meter (Sartorius, Goettingen, Germany).

For radical scavenging activity, the method used by Takao et al. (25) was adopted with suitable modifications from Kumarasamy et al. (26). The diluted sample $(200 \mu \mathrm{L})$ was mixed with $800 \mu \mathrm{L}$ of Tris- $\mathrm{HCl}$ buffer (100 mM, pH=7.4; Sigma-Aldrich, Merck, Goettingen, Germany). To this, $1 \mathrm{~mL}$ of $500 \mu \mathrm{M}$ DPPH in ethanol (Sigma-Aldrich, Merck, Saint Louis, MO, USA) was added, the mixture was vortexed and absorbance was measured using Helios Gamma spectrometer (Thermo Scientific, London, UK) at $517 \mathrm{~nm}$ after $20 \mathrm{~min}$ of incubation in the dark. Percentage of radical scavenging activity was calculated as:

Radical scavenging activity $=\left[\left(A_{\text {control }}-A_{\text {extract }}\right) /\left(A_{\text {control }}\right)\right] \cdot 100$

Acid value of the extracted lipids was determined according to ISO 660:2009 (27). A mass of $1 \mathrm{~g}$ of extracted lipids was dissolved with $50 \mathrm{~mL}$ neutral solvent solution $(50 \mathrm{~mL}$ diethyl ether, $50 \mathrm{~mL}$ ethyl alcohol, and $1 \mathrm{~mL} 1 \%$ phenolphthalein solution (Sigma-Aldrich, Merck). The titration was carried out with $0.1 \mathrm{~mol} / \mathrm{L} \mathrm{NaOH}$ under constant shaking until the formed pink colour was persistent for $15 \mathrm{~s}$. Acid value was calculated as follows:

$$
\text { Acid value }=\frac{56.1 \cdot c \cdot V}{m}
$$

where 56.1 (in $\mathrm{g} / \mathrm{mol}$ ) is the molecular mass of $\mathrm{KOH}, \mathrm{c}$ is the exact concentration (in $\mathrm{mol} / \mathrm{L}$ ) of the standard volumetric sodium or potassium hydroxide solution used, $V$ is the volume (in $\mathrm{mL}$ ) of standard volumetric sodium or potassium hydroxide solution used, and $m$ is the mass (in $\mathrm{g}$ ) of the sample.

Peroxide value of the studied lipids was determined according to ISO 3960:2017 (28). About $3.0 \mathrm{~g}$ fat were mixed with $50 \mathrm{~mL}$ of the solvent mixture (V(glacial acetic acid) $/$ (chloroform)=3:2; Sigma-Aldrich, Merck), $1 \mathrm{~mL}$ freshly prepared saturated potassium iodide (Sigma-Aldrich, Merck) solution and $100 \mathrm{~mL}$ water. The titration was carried out with $0.01 \mathrm{~mol} / \mathrm{L}$ sodium thiosulfate solution (Sigma-Aldrich, Mer$\mathrm{ck})$, using $1 \mathrm{~mL}$ starch solution and $0.1 \mathrm{~g}$ Thyodene $\mathrm{e}^{\mathrm{TM}}$ indicator (Sigma-Aldrich, Merck) until the blue colour disappeared. Peroxide value was calculated as follows:

$$
\text { Peroxide value }=\frac{\left(V-V_{0}\right) \cdot c_{\text {thiosulfate }} \cdot F \cdot 1000}{m}
$$

where $V$ is the volume (in $\mathrm{mL}$ ) of sodium thiosulfate solution used for the determination, $V_{0}$ is the volume (in $\mathrm{mL}$ ) of sodium thiosulfate standard solution used for the blank test, $c_{\text {thiosulfate }}$ is the concentration (in $\mathrm{mol} / \mathrm{L}$ ) of the sodium thiosulfate solution, $m$ is the mass (in $g$ ) of the sample, and $F$ is the factor of $0.01 \mathrm{M}$ sodium thiosulfate solution expressed in mmol of oxygen per $\mathrm{kg}$ of lipid.

\section{Microbial analysis}

Samples of $10 \mathrm{~g}$ were taken at random for each batch, and aseptically weighed into a sterile stomacher bag with $90 \mathrm{~mL}$ of sterile buffered $0.1 \%(\mathrm{~m} / \mathrm{V})$ peptone water (Sigma-Aldrich, Merck) and homogenized for $1 \mathrm{~min}$ in a 400 Stomacher (Seward Ltd., Worthing, UK). Serial decimal dilutions were made, and lactic acid bacteria were determined by plate count on de Man, Rogosa and Sharpe agar (MRS; Oxoid, Basingstoke, UK) after incubation at $30^{\circ} \mathrm{C}$ for $120 \mathrm{~h}$. The number of yeast and mould colonies was determined by plate count on Dichloran Rose Bengal Chloramphenicol (DRBC) agar (Sigma-Aldrich, Merck) after incubation at $25^{\circ} \mathrm{C}$ for $120 \mathrm{~h}$, and total count of mesophilic bacteria was determined on plate count agar (PCA, Sigma-Aldrich, Merck) after incubation at 30 ${ }^{\circ} \mathrm{C}$ for $72 \mathrm{~h}$ in a thermostat. After incubation, colonies were counted according to ISO 7218:2007 (29). The microbiological data were transformed into the logarithm of the number of colony forming units (CFU/g).

\section{Biogenic amine content}

A reversed-phase high-performance liquid chromatography (RP-HPLC) method was used for the quantitative analysis of biogenic amines tryptamine, phenylethylamine, putrescine, cadaverine, histamine, tyramine, spermidine and spermine. The whole cured sausage (edible parts) was cut into small pieces and mashed mechanically using a homogeniser (Moulinex Masterchef 20; Nieune, France). Biogenic amine content was extracted from a homogenized sample with $0.4 \mathrm{~mol} / \mathrm{L}$ perchloric acid (Sigma-Aldrich, Merck). The samples were derivatized for 45 min with dansyl chloride (5-dimethylaminonaphtalene-1-sulfonylchloride) solution in acetone (both Sigma-Aldrich, Merck) at $40^{\circ} \mathrm{C}$ using the modified method of Ben-Gigirey et al. (30). The samples were filtered through a $0.45 \mu \mathrm{m}$ membrane filter (Millipore), and $10 \mu \mathrm{L}$ of the sample were injected into chromatographic system (Agilent 1200 series; Waldbronn, Germany). The analysis was performed using LiChro column CART ${ }^{\oplus} 95$ 125-4 (Merck, Darmstadt, Germany). 


\section{Colour determination}

Meat surface colour was measured using a reflectance spectrophotometer (Minolta CM-2002; Osaka, Japan). Parameters measured in the reflection mode were $L^{*}, a^{*}$ and $b^{*}$ (corresponding to the brightness, redness and yellowness coordinates according to the CIE scale) (31).

\section{Statistical analysis of the data}

The results are expressed as mean value \pm standard error of the mean. One-way analysis of variance (ANOVA) followed by Fisher's least significant difference test, and the Dunnet test were applied when control group was present. Student's $t$-test was used to determine average values of indicators, standard deviations and linear correlations. The correlation was considered reliable when $p<0.05$. SAS Studio v. 5.1 (32) served for data computation.

\section{RESULTS AND DISCUSSION}

\section{Acidity of cold-smoked pork sausages}

During storage, starter cultures in cold-smoked pork sausages affected the acidification of meat. The fermentation of carbohydrates causes the decrease of the active acidity $(\mathrm{pH})$, which leads to the accumulation of organic acids, mainly lactic acid, during storage (33-35). The significant difference between the control and the samples with the added starter culture was detected before day 33 of the study $(p<0.05$ in all samples) (Table 1). We found a negative correlation between the low $\mathrm{pH}$ and high amount of lactic acid bacteria $(\mathrm{R}=-0.621$, $p<0.05)$. Throughout the study, significantly lower $(p<0.05)$ $\mathrm{pH}$ values were found only of samples CR-3 and CR- 6 than of control (CR-8). Taxifolin did not have significant effect on $\mathrm{pH}$

Table 1. Effect of taxifolin and commercial starter cultures on the $\mathrm{pH}$ of cold-smoked pork sausages during storage

\begin{tabular}{ccccc} 
& \multicolumn{4}{c}{$t$ (storage)/day } \\
\cline { 2 - 5 } Sample & 1 & \multicolumn{4}{c}{33} & \multicolumn{3}{c}{128} & 181 \\
\cline { 2 - 5 } CR-1 & $(4.83 \pm 0.02)^{\mathrm{a}}$ & $(4.93 \pm 0.02)^{\mathrm{a}}$ & $(5.24 \pm 0.02)^{\mathrm{a}}$ & $(5.36 \pm 0.01)^{\mathrm{b}}$ \\
CR-2 & $(4.85 \pm 0.01)^{\mathrm{a}}$ & $(4.86 \pm 0.02)^{\mathrm{a}}$ & $(5.31 \pm 0.03)^{\mathrm{a}}$ & $(5.41 \pm 0.01)^{\mathrm{a}}$ \\
CR-3 & $(4.72 \pm 0.01)^{\mathrm{a}}$ & $(4.82 \pm 0.01)^{\mathrm{a}}$ & $(5.17 \pm 0.02)^{\mathrm{b}}$ & $(5.23 \pm 0.03)^{\mathrm{b}}$ \\
CR-4 & $(4.81 \pm 0.02)^{\mathrm{a}}$ & $(4.94 \pm 0.03)^{\mathrm{a}}$ & $(5.25 \pm 0.01)^{\mathrm{a}}$ & $(4.41 \pm 0.01)^{\mathrm{a}}$ \\
CR-5 & $(5.84 \pm 0.02)^{\mathrm{a}}$ & $(4.91 \pm 0.02)^{\mathrm{a}}$ & $(5.31 \pm 0.03)^{\mathrm{a}}$ & $(5.43 \pm 0.02)^{\mathrm{a}}$ \\
CR-6 & $(4.72 \pm 0.03)^{\mathrm{a}}$ & $(4.78 \pm 0.01)^{\mathrm{a}}$ & $(5.07 \pm 0.01)^{\mathrm{b}}$ & $(5.21 \pm 0.01)^{\mathrm{b}}$ \\
CR-7 & $(5.01 \pm 0.01)^{\mathrm{b}}$ & $(5.11 \pm 0.04)^{\mathrm{b}}$ & $(5.34 \pm 0.02)^{\mathrm{a}}$ & $(5.49 \pm 0.02)^{\mathrm{a}}$ \\
CR-8 & $(4.98 \pm 0.02)^{\mathrm{b}}$ & $(5.16 \pm 0.01)^{\mathrm{b}}$ & $(5.29 \pm 0.02)^{\mathrm{a}}$ & $(5.46 \pm 0.01)^{\mathrm{a}}$
\end{tabular}

Results are expressed as mean value \pm standard deviation. Different letters in superscript indicate significant difference between the samples in the same row. CR-1=sausage sample fermented with Leuconostoc carnosum starter culture, CR-2=sausage fermented with Pediococcus pentosaceus and Staphylococcus xylosus, CR-3=sausage fermented with $P$. pentosaceus in high quantity and S. xylosus, CR$-4=$ sausage with taxifolin and $L$. carnosum, CR-5=sausage with taxifolin, P. pentosaceus and S. xylosus, CR-6=sausage with taxifolin, P. pentosaceus in high quantity and S. xylosus, CR-7=sausage with taxifolin, and CR$-8=$ sausage without taxifolin or starter culture (control) during storage. At the end of the study, the final $\mathrm{pH}$ value of cold-smoked pork sausages was around 5 (5.21 to 5.49) except of sample CR-4 (4.41). These data are in agreement with Berardo et al. (36), who claim that when using the Nordic sausage production technology, the final $\mathrm{pH}$ of the sausage is 5 or lower, while when using the Mediterranean technology, the final $\mathrm{pH}$ is between 5 and 6 .

\section{Microbiological profile of cold-smoked pork sausages}

Table 2 shows the microbiological profile of cold-smoked pork sausages. The use of starter cultures increased $(p<0.05)$ the population of lactic acid bacteria compared to the control sample (without starter culture). Our findings are similar to those reported by Kameník et al. (37), who observed that the lactic acid bacteria grow during the first days of fermentation and the population density peaks at $10^{9} \mathrm{cell} / \mathrm{g}$. This is especially important because taxifolin does not inhibit lactic acid bacteria growth in the fermented sausages.

We also evaluated the yeast and mould counts. Taxifolin had an inhibitory effect on mould and yeast in CR-2 and CR- 5 samples up to 33 days, and in CR-1 and CR- 4 mixtures between days 33 and 181, compared to the control sample $(p<0.05)$. Malterud et al. (38) studied the antimicrobial properties of flavonoids from Salix caprea and found that taxifolin was effective against bacteria and fungi. Taxifolin has also been identified in Populus tremuloides black galls, which are a type of plant tumours found in trees resistant to fungal infections (39).

\section{Accumulation of biogenic amines in cold-smoked pork sausages}

Biogenic amines can be detected in raw materials and food products that are formed during metabolic processes. The main biogenic amines produced in the sausage during fermentation are putrescin, cadaverine and tyramine (40). In our study, sausages mainly contained (in $\mathrm{mg} / \mathrm{kg}$ ): putrescine 51.1-86.7, tyramine 15.0-56.6, cadaverine 19.2-34.6 and spermine 1.1-8.8 (data not shown). After 33 days, CR-5 batch had significantly $(p<0.05)$ lower mass fraction of histamine $(2.0 \mathrm{mg} / \mathrm{kg})$ and putrescine $(18.0 \mathrm{mg} / \mathrm{kg})$ than other sausage batches (8.2-19.4 and 37.1-68.5 mg/kg respectively). A significantly $(p<0.05)$ higher mass fraction of tyramine was observed in CR-2 than in CR-5 batch ((35.3 \pm 3.1$)$ and (21.6 \pm 4.3$)$ $\mathrm{mg} / \mathrm{kg}$ respectively). The total biogenic amine content in CR-5 sausages was 25 and $49 \%$ lower $(p<0.05)$ than that in CR-2 and CR-8 (control) sausages. CR-4 batch had a $31 \%$ lower biogenic amine content than CR-1, which had the highest total biogenic amine content ((204.5 \pm 11.6$) \mathrm{mg} / \mathrm{kg})$.

\section{Stability of taxifolin in cold-smoked pork sausages}

A far more objective view of changes in taxifolin content in the cold-smoked pork sausages can be obtained after recalculation of the taxifolin content on a dry mass basis. This recalculation eliminates the effect of variable water content during 
Table 2. Effect of taxifolin and commercial starter cultures on lactic acid bacteria, mesophilic bacteria, yeast and mould counts in cold-smoked pork sausages during storage

\begin{tabular}{|c|c|c|c|c|c|}
\hline \multirow{3}{*}{ Microbiological profile } & \multirow{3}{*}{ Sample } & \multicolumn{4}{|c|}{$t$ (storage)/day } \\
\hline & & 1 & 33 & 52 & 147 \\
\hline & & \multicolumn{4}{|c|}{$N /(\log C F U / g)$} \\
\hline \multirow[t]{8}{*}{ Lactic acid bacteria } & CR-1 & $(7.2 \pm 0.5)^{b}$ & $(6.0 \pm 0.2)^{\mathrm{ab}}$ & $(6.3 \pm 0.4)^{\mathrm{a}}$ & $(4.7 \pm 0.3)^{\mathrm{a}}$ \\
\hline & CR-2 & $(7.0 \pm 0.3)^{\mathrm{b}}$ & $(6.3 \pm 0.3)^{\mathrm{ab}}$ & $(6.4 \pm 0.3)^{\mathrm{a}}$ & $(4.4 \pm 0.4)^{\mathrm{a}}$ \\
\hline & CR-3 & $(7.0 \pm 0.4)^{\mathrm{ab}}$ & $(6.6 \pm 0.5)^{b}$ & $(6.7 \pm 0.4)^{\mathrm{a}}$ & $(5.8 \pm 0.4)^{\mathrm{a}}$ \\
\hline & CR-4 & $(7.3 \pm 0.4)^{b}$ & $(5.2 \pm 0.4)^{\mathrm{ab}}$ & $(6.3 \pm 0.3)^{\mathrm{a}}$ & $(4.3 \pm 0.3)^{\mathrm{a}}$ \\
\hline & CR-5 & $(7.1 \pm 0.5)^{\mathrm{b}}$ & $(6.4 \pm 0.3)^{\mathrm{ab}}$ & $(6.9 \pm 0.4)^{\mathrm{a}}$ & $(5.0 \pm 0.4)^{\mathrm{a}}$ \\
\hline & CR-6 & $(6.3 \pm 0.3)^{\mathrm{a}}$ & $(7.0 \pm 0.3)^{\mathrm{b}}$ & $(6.9 \pm 0.2)^{\mathrm{a}}$ & $(6.2 \pm 0.3)^{\mathrm{a}}$ \\
\hline & CR-7 & $(6.2 \pm 0.4)^{\mathrm{a}}$ & $(6.1 \pm 0.3)^{\mathrm{ab}}$ & $(3.7 \pm 0.3)^{b}$ & $(3.0 \pm 0.2)^{b}$ \\
\hline & CR-8 & $(6.5 \pm 0.4)^{\mathrm{a}}$ & $(5.7 \pm 0.3)^{\mathrm{a}}$ & $(3.9 \pm 0.3)^{\mathrm{b}}$ & $(3.3 \pm 0.3)^{b}$ \\
\hline \multirow[t]{8}{*}{ Total count of yeasts and moulds } & CR-1 & $(3.0 \pm 0.1)^{\mathrm{a}}$ & $(3.1 \pm 0.2)^{\mathrm{ab}}$ & $(3.2 \pm 0.3)^{b}$ & $(3.3 \pm 0.5)^{\mathrm{b}}$ \\
\hline & CR-2 & $(2.0 \pm 0.2)^{\mathrm{b}}$ & $(2.7 \pm 0.2)^{\mathrm{a}}$ & $(3.5 \pm 0.2)^{\mathrm{ab}}$ & $(4.0 \pm 0.3)^{\mathrm{ab}}$ \\
\hline & CR-3 & $(2.6 \pm 0.2)^{\mathrm{ab}}$ & $(2.9 \pm 0.3)^{\mathrm{a}}$ & $(3.3 \pm 0.3)^{\mathrm{ab}}$ & $(4.0 \pm 0.3)^{a b}$ \\
\hline & CR-4 & $(3.3 \pm 0.1)^{\mathrm{a}}$ & $(3.2 \pm 0.2)^{\mathrm{ab}}$ & $(3.2 \pm 0.3)^{b}$ & $(3.2 \pm 0.4)^{\mathrm{b}}$ \\
\hline & CR-5 & $(2.2 \pm 0.3)^{b}$ & $(2.7 \pm 0.3)^{\mathrm{a}}$ & $(3.8 \pm 0.2)^{\mathrm{ab}}$ & $(4.2 \pm 0.4)^{a}$ \\
\hline & CR-6 & $(2.9 \pm 0.2)^{\mathrm{ab}}$ & $(3.7 \pm 0.3)^{\mathrm{ab}}$ & $(3.9 \pm 0.2)^{\mathrm{ab}}$ & $(4.1 \pm 0.3)^{\mathrm{ab}}$ \\
\hline & CR-7 & $(3.0 \pm 0.2)^{\mathrm{ab}}$ & $(3.9 \pm 0.2)^{b}$ & $(3.9 \pm 0.3)^{\mathrm{a}}$ & $(4.0 \pm 0.3)^{\mathrm{a}}$ \\
\hline & CR-8 & $(3.9 \pm 0.3)^{\mathrm{a}}$ & $(4.1 \pm 0.2)^{\mathrm{b}}$ & $(4.3 \pm 0.4)^{\mathrm{a}}$ & $(4.4 \pm 0.4)^{\mathrm{a}}$ \\
\hline \multirow{8}{*}{$\begin{array}{c}\text { Total count of mesophilic } \\
\text { bacteria }\end{array}$} & CR-1 & $(7.4 \pm 0.3)^{\mathrm{a}}$ & $(6.9 \pm 0.3)^{\mathrm{ab}}$ & $(6.3 \pm 0.3)^{\mathrm{a}}$ & $\left(4.7 \pm 0.3^{a}\right.$ \\
\hline & CR-2 & $(7.5 \pm 0.3)^{\mathrm{a}}$ & $(7.0 \pm 0.5)^{\mathrm{ab}}$ & $(6.5 \pm 0.2)^{\mathrm{a}}$ & $(4.5 \pm 0.4)^{\mathrm{a}}$ \\
\hline & CR-3 & $(8.2 \pm 0.4)^{\mathrm{a}}$ & $(7.6 \pm 0.2)^{b}$ & $(6.4 \pm 0.3)^{\mathrm{a}}$ & $(5.8 \pm 0.3)^{\mathrm{b}}$ \\
\hline & CR-4 & $(7.4 \pm 0.5)^{\mathrm{a}}$ & $(6.9 \pm 0.4)^{\mathrm{a}}$ & $(4.8 \pm 0.4)^{b}$ & $(4.0 \pm 0.2)^{\mathrm{a}}$ \\
\hline & CR-5 & $(7.5 \pm 0.4)^{\mathrm{a}}$ & $(7.7 \pm 0.3)^{\mathrm{b}}$ & $(6.8 \pm 0.2)^{\mathrm{a}}$ & $(6.0 \pm 0.4)^{b}$ \\
\hline & CR-6 & $(8.1 \pm 0.3)^{\mathrm{a}}$ & $(8.0 \pm 0.3)^{b}$ & $(7.0 \pm 0.4)^{\mathrm{a}}$ & $(6.1 \pm 0.3)^{b}$ \\
\hline & CR-7 & $(8.2 \pm 0.3)^{\mathrm{a}}$ & $(6.9 \pm 0.4)^{\mathrm{ab}}$ & $(6.2 \pm 0.3)^{\mathrm{a}}$ & $(3.0 \pm 0.1)^{\mathrm{a}}$ \\
\hline & CR-8 & $(7.0 \pm 0.2)^{\mathrm{a}}$ & $(6.2 \pm 0.3)^{\mathrm{a}}$ & $(6.4 \pm 0.4)^{\mathrm{a}}$ & $(3.3 \pm 0.2)^{a}$ \\
\hline
\end{tabular}

Results are expressed as mean value \pm standard deviation. Different letters in superscript indicate significant difference between the samples in the same row. Sample abbreviations are given in Table 1

production. After 181 days of storage, total taxifolin content was the highest in CR- 4 batch $(0.027 \mathrm{mg} / \mathrm{kg}$, followed by CR- 6 batch $(0.025 \mathrm{mg} / \mathrm{kg})(\mathrm{p}<0.05)$, while the sausages treated only with taxifolin (CR-7) retained only $0.012 \mathrm{mg} / \mathrm{kg}$ (Table 3). UPLC analysis demonstrated that taxifolin was more stable in samples fermented with commercial starter cultures, which could be related to a stronger acidification during the first 33 days.

\section{Antioxidant properties of cold-smoked pork sausages}

The effect of taxifolin on antioxidant properties of cold-smoked pork sausages during storage is shown in Table 4. CR-4 sample had the highest free radical scavenging activity
((77.4 \pm 1.3$) \%)$ on the first day of the study, followed by CR-5, CR-6 and CR-7 ((76.9 \pm 0.8$),(76.7 \pm 0.7)$ and (73.0 \pm 0.4$) \%$, respectively) $(p<0.05)$. Mixtures containing taxifolin with starter cultures bind free radicals better than taxifolin alone. On the last day of the study (day 181), the highest antioxidant activity was detected in CR-4, CR-5 and CR- 6 batches ((55.6 \pm 0.5$)$, (51.1 \pm 0.3$)$ and (54.5 \pm 0.4$) \%$, respectively). Kim et al. (41) stated that taxifolin was more effective antioxidant than BHA and a-tocopherol. Taxifolin has two aromatic rings that have two phenolic groups $(-\mathrm{OH})$ at the meta and para positions. It is this arrangement that is the chief determinant of the strong antioxidant capacity of phenolic compounds (42).

Table 3. Taxifolin content of cold-smoked pork sausages on dry mass basis during storage

\begin{tabular}{|c|c|c|c|c|}
\hline \multirow{3}{*}{ Sample } & \multicolumn{4}{|c|}{$t$ (storage)/day } \\
\hline & 1 & 33 & 128 & 181 \\
\hline & \multicolumn{4}{|c|}{$w($ taxifolin)/(mg/kg) } \\
\hline CR-4 & $(0.045 \pm 0.004)^{\mathrm{a} 2}$ & $(0.041 \pm 0.003)^{\mathrm{a} 2}$ & $(0.033 \pm 0.001)^{\mathrm{b} 2}$ & $(0.027 \pm 0.002)^{c 2}$ \\
\hline CR-5 & $(0.043 \pm 0.003)^{\mathrm{a} 23}$ & $(0.038 \pm 0.002)^{\mathrm{a} 2}$ & $(0.029 \pm 0.002)^{\mathrm{b} 2}$ & $(0.022 \pm 0.003)^{\mathrm{c} 2}$ \\
\hline CR-6 & $(0.041 \pm 0.003)^{\mathrm{a} 23}$ & $(0.038 \pm 0.003)^{\mathrm{a} 2}$ & $(0.030 \pm 0.001)^{\mathrm{b} 2}$ & $(0.025 \pm 0.001)^{c 2}$ \\
\hline CR-7 & $(0.039 \pm 0.004)^{a 3}$ & $(0.030 \pm 0.001)^{\mathrm{b} 3}$ & $(0.022 \pm 0.002)^{c 3}$ & $(0.012 \pm 0.001)^{\mathrm{d} 3}$ \\
\hline
\end{tabular}

Results are expressed as mean value \pm standard deviation. Different letters in superscript indicate significant differences between the samples in the same row and different numbers in superscript indicate significant differences between the samples in the same column. Sample abbreviations are given in Table 1 
Table 4. Effect of taxifolin and commercial starter cultures on antioxidant properties of cold-smoked pork sausages during storage

\begin{tabular}{|c|c|c|c|c|c|}
\hline \multirow{2}{*}{ Antioxidant property } & \multirow{2}{*}{ Sample } & \multicolumn{4}{|c|}{$t$ (storage)/day } \\
\hline & & 1 & 33 & 128 & 181 \\
\hline \multirow[t]{8}{*}{ Scavenging activity/\% } & CR-1 & $(64.6 \pm 0.5)^{\mathrm{a}}$ & $(57.4 \pm 0.8)^{a}$ & $(52.6 \pm 0.6)^{a}$ & $(43.3 \pm 0.5)^{\mathrm{a}}$ \\
\hline & CR-2 & $(62.6 \pm 0.7)^{\mathrm{a}}$ & $(58.8 \pm 0.4)^{\mathrm{a}}$ & $(50.3 \pm 0.6)^{\mathrm{a}}$ & $(44.6 \pm 0.5)^{\mathrm{a}}$ \\
\hline & CR-3 & $(64.2 \pm 0.3)^{\mathrm{a}}$ & $(57.1 \pm 0.4)^{\mathrm{a}}$ & $(51.1 \pm 0.4)^{\mathrm{a}}$ & $(42.8 \pm 0.6)^{\mathrm{a}}$ \\
\hline & CR-4 & $(77.4 \pm 0.3)^{b}$ & $(74.3 \pm 0.7)^{\mathrm{b}}$ & $(65.2 \pm 0.6)^{b}$ & $(55.6 \pm 0.5)^{\mathrm{b}}$ \\
\hline & CR-5 & $(76.9 \pm 0.8)^{\mathrm{b}}$ & $(73.6 \pm 0.4)^{b}$ & $(60.4 \pm 0.6)^{b}$ & $(51.1 \pm 0.3)^{\mathrm{b}}$ \\
\hline & CR-6 & $(76.7 \pm 0.7)^{b}$ & $(73.2 \pm 0.4)^{b}$ & $(64.0 \pm 0.4)^{b}$ & $(54.5 \pm 0.4)^{b}$ \\
\hline & CR-7 & $(73.0 \pm 0.4)^{\mathrm{b}}$ & $(68.1 \pm 0.4)^{\mathrm{b}}$ & $(53.5 \pm 0.4)^{\mathrm{a}}$ & $(47.1 \pm 0.7)^{\mathrm{a}}$ \\
\hline & CR-8 & $(63.3 \pm 0.5)^{\mathrm{a}}$ & $(57.7 \pm 0.5)^{\mathrm{a}}$ & $(50.9 \pm 0.4)^{\mathrm{a}}$ & $(44.7 \pm 0.6)^{\mathrm{a}}$ \\
\hline \multirow[t]{8}{*}{ Acid value/(mg/kg) } & CR-1 & $(3.7 \pm 0.2)^{\mathrm{a}}$ & $(7.1 \pm 0.3)^{\mathrm{a}}$ & $(13.4 \pm 0.4)^{\mathrm{a}}$ & $(24.2 \pm 0.3)^{\mathrm{a}}$ \\
\hline & CR-2 & $(4.2 \pm 0.2)^{\mathrm{a}}$ & $(6.8 \pm 0.3)^{\mathrm{a}}$ & $(14.3 \pm 0.3)^{\mathrm{a}}$ & $(26.5 \pm 0.3)^{\mathrm{a}}$ \\
\hline & CR-3 & $(3.9 \pm 0.3)^{\mathrm{a}}$ & $(7.2 \pm 0.2)^{\mathrm{a}}$ & $(12.3 \pm 0.2)^{\mathrm{a}}$ & $(25.7 \pm 0.5)^{\mathrm{a}}$ \\
\hline & CR-4 & $(2.1 \pm 0.2)^{\mathrm{b}}$ & $(4.4 \pm 0.3)^{\mathrm{b}}$ & $(7.9 \pm 0.3)^{\mathrm{b}}$ & $(17.1 \pm 0.4)^{b}$ \\
\hline & CR-5 & $(2.5 \pm 0.3)^{b}$ & $(4.9 \pm 0.2)^{\mathrm{b}}$ & $(9.3 \pm 0.3)^{\mathrm{b}}$ & $(20.5 \pm 0.4)^{\mathrm{a}}$ \\
\hline & CR-6 & $(2.5 \pm 0.2)^{b}$ & $(5.4 \pm 0.3)^{\mathrm{b}}$ & $(10.7 \pm 0.4)^{\mathrm{ab}}$ & $(21.8 \pm 0.2)^{\mathrm{a}}$ \\
\hline & CR-7 & $(2.6 \pm 0.2)^{\mathrm{b}}$ & $(5.7 \pm 0.3)^{\mathrm{ab}}$ & $(12.4 \pm 0.2)^{\mathrm{a}}$ & $(24.2 \pm 0.3)^{\mathrm{a}}$ \\
\hline & CR-8 & $(3.7 \pm 0.3)^{\mathrm{a}}$ & $(7.5 \pm 0.2)^{\mathrm{a}}$ & $(13.4 \pm 0.3)^{\mathrm{a}}$ & $(25.4 \pm 0.2)^{\mathrm{a}}$ \\
\hline \multirow{8}{*}{$\begin{array}{l}\text { Peroxide value/(mmol } \\
\mathrm{O}_{2} \text { per kg lipid) }\end{array}$} & CR-1 & $(0.28 \pm 0.04)^{\mathrm{a}}$ & $(0.65 \pm 0.02)^{\mathrm{a}}$ & $(0.87 \pm 0.04)^{\mathrm{a}}$ & $(1.58 \pm 0.07)^{\mathrm{a}}$ \\
\hline & CR-2 & $(0.25 \pm 0.03)^{\mathrm{a}}$ & $(0.59 \pm 0.03)^{\mathrm{a}}$ & $(0.91 \pm 0.06)^{\mathrm{a}}$ & $(1.34 \pm 0.08)^{\mathrm{a}}$ \\
\hline & CR-3 & $(0.34 \pm 0.03)^{\mathrm{a}}$ & $(0.61 \pm 0.02)^{\mathrm{a}}$ & $(0.94 \pm 0.03)^{a}$ & $(1.49 \pm 0.05)^{a}$ \\
\hline & CR-4 & $(0.25 \pm 0.01)^{\mathrm{a}}$ & $(0.31 \pm 0.01)^{\mathrm{b}}$ & $(0.63 \pm 0.07)^{b}$ & $(1.15 \pm 0.04)^{b}$ \\
\hline & CR-5 & $(0.26 \pm 0.03)^{\mathrm{a}}$ & $(0.42 \pm 0.01)^{\mathrm{b}}$ & $(0.74 \pm 0.02)^{b}$ & $(1.26 \pm 0.06)^{a b}$ \\
\hline & CR-6 & $(0.30 \pm 0.02)^{\mathrm{a}}$ & $(0.41 \pm 0.02)^{\mathrm{b}}$ & $(0.69 \pm 0.05)^{b}$ & $(1.29 \pm 0.05)^{\mathrm{ab}}$ \\
\hline & CR-7 & $(0.21 \pm 0.02)^{\mathrm{a}}$ & $(0.40 \pm 0.04)^{b}$ & $(0.75 \pm 0.03)^{b}$ & $(1.45 \pm 0.03)^{a}$ \\
\hline & CR-8 & $(0.27 \pm 0.03)^{\mathrm{a}}$ & $(0.58 \pm 0.03)^{a}$ & $(0.92 \pm 0.08)^{a}$ & $(1.32 \pm 0.04)^{a}$ \\
\hline
\end{tabular}

Results are expressed as mean value \pm standard deviation. Different letters in superscript indicate significant differences between the samples in the same row. Sample abbreviations are given in Table 1

At the beginning of the study, we found low peroxide values (less than $1.00 \mathrm{mmol}$ of $\mathrm{O}_{2}$ per $\mathrm{kg}$ of lipid) in our sausages. Lorenzo et al. (43) state that the starter culture used in fermented sausages inhibits the formation of peroxide value during storage, while Falowo et al. (44) indicate that slower lipid spoilage in fermented sausages results from a decrease of moisture and the denaturation of enzymes in the meat during storage. In our study, the highest peroxide value was found in control samples of cold-smoked pork sausages, and the lowest in the samples with taxifolin and starter culture. Thus, the changes in peroxide values in fermented sausages indicate that taxifolin effectively inhibits chain reactions occurring in lipid peroxidation. These results coincide with the findings of Semenova et al. (45), who stated that the taxifolin even at the minimal mass fraction of $0.001 \%$ inhibits the oxidation of the lipid fraction in the minced meat, because it reduces peroxide value by $58.60 \%$ compared to the minced meat produced by the traditional recipe. Bakalivanova and Kaloyanov (46) also stated that taxifolin has a beneficial effect on lipid peroxidase and is suitable for use in sausage production as an antioxidant.

On the first day of the study, the lowest acid value ( $\mathrm{Ta}$ ble 4) was determined in batches CR-4, CR-5, CR- 6 and CR-7 $((2.1 \pm 0.2),(2.5 \pm 0.3),(2.4 \pm 0.2)$ and $(2.6 \pm 0.2) \mathrm{mg} \mathrm{NaOH}$ per kg of lipid, respectively) $(\mathrm{p}<0.05)$. Gonzales et al. (16) state that flavonoids are able to bind metals that are capable of catalysing many biological processes such as fat hydrolysis. Topal et al. (2) confirmed these results; they also found that taxifolin can bind free radicals and metal ions. At the end of the study (day 181), the significantly lower acid value was determined only in batch CR-4 $((17.1 \pm 0.4) \mathrm{mg} / \mathrm{kg})(\mathrm{p}<0.05)$. In the samples, a strong negative correlation was found between $\mathrm{pH}$ and peroxide value $(\mathrm{R}=-0.831, \mathrm{p}<0.05)$ between $\mathrm{pH}$ and acid value $(-0.874, p<0.05)$ (data not shown). We also found that the duration of storage influenced acid and peroxide values $(p<0.05)$.

\section{Evaluation of colour parameters of cold-smoked pork sausages}

We determined that the colour parameters $\left(L^{*}, a^{*}\right.$ and $\left.b^{*}\right)$ of all preparations and final meat products were significantly $(p<0.05)$ influenced by the used taxifolin and starter cultures and storage time (Table 5). Some reports indicate that changes in the colour of fermented sausage are influenced only by maturation time, but not by starter cultures (47). The redness ( $a^{*}$ ) of investigated cold-smoked sausages during storage decreased in all samples, but significantly only in samples CR-5, CR-6 and CR-7 from the 33rd day of investigation $(p<0.05)$. 
Table 5. Effect of taxifolin and commercial starter cultures on the colour parameters of cold-smoked pork sausages during storage

\begin{tabular}{|c|c|c|c|c|c|}
\hline \multirow{2}{*}{$\begin{array}{l}\text { Colour } \\
\text { parameter }\end{array}$} & \multirow{2}{*}{ Sample } & \multicolumn{4}{|c|}{$t($ storage $) /$ day } \\
\hline & & 1 & 33 & 128 & 181 \\
\hline \multirow[t]{8}{*}{$L^{*}$} & CR-1 & $(36.6 \pm 0.3)^{b}$ & $(43.4 \pm 0.4)^{\mathrm{a}}$ & $(39.9 \pm 0.0)^{\mathrm{a}}$ & $(39.6 \pm 0.1)^{a}$ \\
\hline & CR-2 & $(40.1 \pm 0.7)^{\mathrm{a}}$ & $(45.8 \pm 0.0)^{\mathrm{b}}$ & $(45.1 \pm 0.9)^{b}$ & $(39.6 \pm 0.1)^{\mathrm{a}}$ \\
\hline & CR-3 & $(35.3 \pm 0.3)^{\mathrm{b}}$ & $(43.1 \pm 0.5)^{\mathrm{a}}$ & $(41.1 \pm 0.1)^{\mathrm{a}}$ & $(40.1 \pm 0.1)^{\mathrm{a}}$ \\
\hline & CR-4 & $(38.9 \pm 0.5)^{\mathrm{a}}$ & $(44.4 \pm 0.3)^{\mathrm{a}}$ & $(43.0 \pm 2.7)^{\mathrm{a}}$ & $(38.4 \pm 0.2)^{\mathrm{a}}$ \\
\hline & CR-5 & $(39.9 \pm 0.4)^{\mathrm{a}}$ & $(47.6 \pm 0.1)^{b}$ & $(45.6 \pm 0.3)^{b}$ & $(46.7 \pm 0.0)^{b}$ \\
\hline & CR-6 & $(40.4 \pm 0.7)^{\mathrm{a}}$ & $(48.1 \pm 0.1)^{b}$ & $(46.8 \pm 0.0)^{b}$ & $(43.2 \pm 0.3)^{b}$ \\
\hline & CR-7 & $(32.2 \pm 0.4)^{b}$ & $(41.2 \pm 0.4)^{a}$ & $(41.0 \pm 0.3)^{\mathrm{a}}$ & $(39.3 \pm 0.1)^{\mathrm{a}}$ \\
\hline & CR-8 & $(33.8 \pm 0.6)^{b}$ & $(40.6 \pm 0.1)^{\mathrm{a}}$ & $(40.0 \pm 0.1)^{\mathrm{a}}$ & $(38.4 \pm 0.1)^{\mathrm{a}}$ \\
\hline \multirow[t]{8}{*}{$a^{*}$} & CR-1 & $(15.7 \pm 0.5)^{\mathrm{a}}$ & $(25.9 \pm 0.4)^{b}$ & $(16.4 \pm 0.0)^{b}$ & $(14.8 \pm 0.0)^{\mathrm{a}}$ \\
\hline & CR-2 & $(16.1 \pm 0.4)^{\mathrm{ab}}$ & $(23.3 \pm 0.3)^{\mathrm{b}}$ & $\left(15.7 \pm 0.6^{b}\right.$ & $(15.5 \pm 0.1)^{\mathrm{a}}$ \\
\hline & CR-3 & $(15.6 \pm 0.6)^{\mathrm{a}}$ & $(18.0 \pm 0.5)^{\mathrm{a}}$ & $(13.3 \pm 0.0)^{\mathrm{a}}$ & $(11.8 \pm 0.0)^{\mathrm{ab}}$ \\
\hline & CR-4 & $(16.0 \pm 0.3)^{\mathrm{a}}$ & $(21.0 \pm 0.2)^{b}$ & $(14.1 \pm 2.6)^{\mathrm{a}}$ & $(15.8 \pm 0.0)^{\mathrm{a}}$ \\
\hline & CR-5 & $(18.3 \pm 0.5)^{\mathrm{b}}$ & $(20.4 \pm 0.3)^{\mathrm{b}}$ & $(15.9 \pm 0.1)^{\mathrm{b}}$ & $(14.2 \pm 0.0)^{\mathrm{a}}$ \\
\hline & CR-6 & $(17.5 \pm 0.6)^{\mathrm{ab}}$ & $(20.6 \pm 0.6)^{b}$ & $(14.9 \pm 0.0)^{\mathrm{a}}$ & $(14.7 \pm 0.1)^{\mathrm{a}}$ \\
\hline & CR-7 & $(15.4 \pm 0.7)^{\mathrm{a}}$ & $(20.4 \pm 0.1)^{\mathrm{b}}$ & $(13.7 \pm 0.1)^{\mathrm{a}}$ & $(10.9 \pm 0.1)^{\mathrm{ab}}$ \\
\hline & CR-8 & $(14.4 \pm 0.7)^{\mathrm{a}}$ & $(14.4 \pm 0.1)^{\mathrm{a}}$ & $(12.8 \pm 0.0)^{a}$ & $(8.4 \pm 0.1)^{\mathrm{b}}$ \\
\hline \multirow[t]{8}{*}{$b^{*}$} & CR-1 & $(13.0 \pm 0.2)^{\mathrm{a}}$ & $(19.5 \pm 0.4)^{\mathrm{a}}$ & $(8.9 \pm 0.0)^{\mathrm{a}}$ & $(7.4 \pm 0.1)^{\mathrm{a}}$ \\
\hline & CR-2 & $(13.0 \pm 0.2)^{\mathrm{a}}$ & $(20.9 \pm 0.2)^{\mathrm{a}}$ & $(10.0 \pm 0.4)^{a}$ & $(9.1 \pm 0.1)^{\mathrm{a}}$ \\
\hline & CR-3 & $(11.7 \pm 0.6)^{a}$ & $(13.0 \pm 0.3)^{\mathrm{a}}$ & $(7.4 \pm 0.0)^{\mathrm{a}}$ & $(6.2 \pm 0.1)^{\mathrm{a}}$ \\
\hline & CR-4 & $(12.5 \pm 0.4)^{\mathrm{a}}$ & $(15.7 \pm 0.2)^{\mathrm{a}}$ & $(10.6 \pm 1.3)^{\mathrm{a}}$ & $(8.7 \pm 0.0)^{\mathrm{a}}$ \\
\hline & CR-5 & $(13.0 \pm 0.6)^{a}$ & $(16.5 \pm 0.0)^{\mathrm{a}}$ & $(9.3 \pm 0.0)^{\mathrm{a}}$ & $(9.2 \pm 0.0)^{\mathrm{a}}$ \\
\hline & CR-6 & $(13.2 \pm 0.5)^{\mathrm{a}}$ & $(15.7 \pm 0.5)^{\mathrm{a}}$ & $(8.5 \pm 0.0)^{a}$ & $(8.2 \pm 0.0)^{\mathrm{a}}$ \\
\hline & CR-7 & $(10.9 \pm 0.2)^{a}$ & $(19.9 \pm 0.3)^{\mathrm{a}}$ & $(10.6 \pm 0.1)^{\mathrm{a}}$ & $(7.1 \pm 0.0)^{\mathrm{a}}$ \\
\hline & CR-8 & $(11.9 \pm 0.3)^{\mathrm{a}}$ & $(18.0 \pm 0.1)^{\mathrm{a}}$ & $(11.3 \pm 0.0)^{\mathrm{a}}$ & $(10.1 \pm 0.1)^{\mathrm{a}}$ \\
\hline
\end{tabular}

Results are expressed as mean value \pm standard deviation. Different letters in superscript indicate significant differences between the samples in the same row. Sample abbreviations are given in Table 1

\section{CONCLUSIONS}

In this study, we evaluated the effect of taxifolin on the microbiological profile of cold-smoked pork sausages, as well as their acidity, biogenic amine content, and colour parameters. The stability and antioxidant activity of taxifolin were also evaluated. We found that taxifolin increased the acidity of cold-smoked pork sausages during storage, with lower $\mathrm{pH}$ values found in samples CR-3 and CR-6. Taxifolin had an inhibitory effect on mould and yeast, and inhibited fat peroxidation processes, leading to lower acid values. A negative correlation between the $\mathrm{pH}$ and acid value was also found. Taxifolin and a commercial starter culture with Pediococcus pentosaceus and Staphylococcus xylosus could reduce the accumulation of total biogenic amine values, and also stabilize and slow down the rate of lipolysis and effectively inhibit the processes of lipid peroxidation. On the other hand, taxifolin causes the colour to fade, which could be unfavourable effect, and modification of sausage fermentation would be needed. Taxifolin should be studied in detail to improve the food processes and provide maximum beneficial health effects to the consumers with optimum nutritional and functional properties. It is very important to continue working with different meat products and taxifolin to better understand the effect of interactions of different compounds. The outcome of this study can help develop new fermented meat products with beneficial health aspects.

\section{CONFLICT OF INTEREST}

The authors declare no conflict of interest.

\section{ORCID IDs}

S. Gustiene (1) https://orcid.org/0000-0001-9258-6261

G. Zaborskiene () https://orcid.org/0000-0001-5917-9146

A. Rokaityte (1) https://orcid.org/0000-0003-3073-637X

R. Riešute (1) https://orcid.org/0000-0003-1791-3562

\section{REFERENCES}

1. Vladimirov YA, Proskurnina EV, Demin EM, Matveeva NS, Lubitskiy OB, Novikov AA, et al. Dihydroquercetin (taxifolin) and other flavonoids as inhibitors of free radical formation at key stages of apoptosis. Biochemistry Moscow. 2009;74(3):301-7.

https://doi.org/10.1134/S0006297909030092

2. Topal F, Nar M, Gocer H, Kalin P, Kocyigit UM, Gülçin I, Alwasel SH. Antioxidant activity of taxifolin: An activity-structure relationship. J Enzyme Inhib Med Chem. 2016;31(4):674-83.

https://doi.org/10.3109/14756366.2015.1057723

3. Schauss AG, Tselyico SS, Kuznetsova VA, Yegorova I. Toxicological and genotoxicity assessment of a 
dihydroquercetin-rich Dahurian larch tree (Larix gmelinii Rupr) extract (Lavitol). Int J Toxicol. 2015;34(2):162-81. https://doi.org/10.1177/1091581815576975

4. Trouillas $P$, Fagnère $C$, Lazzaroni $R$, Calliste $C$, Marfak $A$, Duroux JA. A theoretical study of the conformational behavior and electronic structure of taxifolin correlated with the free radical-scavenging activity. Food Chem. 2004;88(4):571-82. https://doi.org/10.1016/j.foodchem.2004.02.009

5. Theriault A, Wang Q, Van Iderstine SC, Chen B, Franke AA, Adeli K. Modulation of hepatic lipoprotein synthesis and secretion by taxifolin, a plant flavonoid. J Lip Res. 2000; 41(12):1969-79.

6. Delporte C, Backhouse N, Erazo S, Negrete R, Vidal P, Silva $\mathrm{X}$, et al. Analgesic-antiinflammatory properties of Proustia pyrifolia. J Ethnopharm. 2005;99(1):119-24. https://doi.org/10.1016/j.jep.2005.02.012

7. Guo H, Zhang X, Cui Y, Zhou H, Xu D, Shan T, et al. Taxifolin protects against cardiac hypertrophy and fibrosis during biomechanical stress of pressure overload. Toxicol Appl Pharmacol. 2015;287(2):168-77.

https://doi.org/10.1016/j.taap.2015.06.002

8. Dok-Go H, Lee KH, Kim HJ, Lee EH, Lee J, Song YS, et al. Neuroprotective effects of antioxidative flavonoids, quercetin, (+)-dihydroquercetin and quercetin 3-methyl ether, isolated from Opuntia ficus-indica var. saboten. Brain Res. 2003;965(1-2):130-6.

https://doi.org/10.1016/S0006-8993(02)04150-1

9. Bobolaki N, Photiades A, Grigorakis S, Makris DP. Empirical kinetic modelling of the effect of L-ascorbic acid on the $\mathrm{Cu}(\mathrm{II})$-induced oxidation of quercetin. Chem Eng. 2018; 2(4):46.

https://doi.org/10.3390/chemengineering2040046

10. Kumar Vivekanandhan D, Ranjan Prasad Verma P, Kumar Singh S. Emerging technologies for improving bioavailability of polyphenols. Curr Nutr Food Sci. 2016;12(1):12-22.

11. West ME, Mauer LJ. Development of an integrated approach for the stability testing of flavonoids and ascorbic acid in powders. Food Chem. 2011;129(1):51-8.

https://doi.org/10.1016/j.foodchem.2011.03.131

12. Shikov AN, Pozharitskaya ON, Miroshnyk I, Mirza S, Urakova IN, Hirsjävi S, et al. Nanodispersions of taxifolin: Impact of solid-state properties on dissolution behavior. Int J Pharm. 2009;377(1-2):148-52.

https://doi.org/10.1016/j.ijpharm.2009.04.044

13. Commission Regulation (EU) No 1129/2011 of 11 November amending Annex II to Regulation (EC) No 1333/2008 of the European Parliament and of the Council by establishing a Union list of food additives. Off J EU. L 295; 2011. Available from: https://eur-lex.europa.eu/legal-content/EN/TXT/PD$\mathrm{F}$ /?uri=CELEX:32011R1129\&from=EN.

14. Regulation (EU) $2015 / 2283$ of the European Parliament and of the Council of 25 November 2015 on novel foods, amending Regulation (EU) No 1169/2011 of the European Parliament and of the Council and repealing Regulation (EC) No 258/97 of the European Parliament and of the Council and Commission Regulation (EC) No 1852/2001. Off J EU. L 327. Available from:

https://eur-lex.europa.eu/legal-content/en/TXT/?uri=CELEX\%3A32015R2283.

15. EFSA Panel on Dietetic Products, Nutrition and Allergies (NDA), Turck D, Bresson JL, Burlingame B, Dean T, et al. Statement on the safety of taxifolin-rich extract from Dahurian larch (Larix gmelinii). EFSA J. 2017;15(11):e05059.

https://doi.org/10.2903/j.efsa.2017.5059

16. Gonzales GB, Smagghe G, Grootaert C, Zotti M, Raes K, Van Camp J. Flavonoid interactions during digestion, absorption, distribution and metabolism: A sequential structure-activity/property relationship-based approach in the study of bioavailability and bioactivity. Drug Metab Rev. 2015;47(2):175-90.

https://doi.org/10.3109/03602532.2014.1003649

17. Chatzopoulou A, Karioti A, Gousiadou C, Lax Vivancos V, Kyriazopoulos P, Golegou S, Skaltsa H. Depsides and other polar constituents from Origanum dictamnus L. and their in vitro antimicrobial activity in clinical strains. J Agr Food Chem. 2010;58(10):6064-8.

https://doi.org/10.1021/jf904596m

18. Willför SM, Ahotupa MO, Hemming JE, Reunanen MHT, Eklund PC, Sjöholm RE, et al. Antioxidant activity of knotwood extractives and phenolic compounds of selected tree species. J Agr Food Chem. 2003;51(26):7600-6.

https://doi.org/10.1021/jf030445h

19. Bais HP, Walker TS, Kennan AJ, Stermitz FR, Vivanco JM. Structure-dependent phytotoxicity of catechins and other flavonoids: Flavonoid conversions by cell-free protein extracts of Centaurea maculosa (spotted knapweed) roots. J Agr Food Chem. 2003:51(4);897-901.

https://doi.org/10.1021/jf020978a

20. Ciuciu Simion AM, Vizireanu C, Alexe P, Franco I, Carballo J. Effect of the use of selected starter cultures on some quality, safety and sensorial properties of Dacia sausage, a traditional Romanian dry-sausage variety. Food Control. 2014;35(1):123-31.

https://doi.org/10.1016/j.foodcont.2013.06.047

21. Rokaityte A, Zaborskiene G, Gunstiene S, Raudonis R, Janulis V, Garmiene G, Stimbirys A. Effect of taxifolin on physicochemical and microbiological parameters of dry-cured pork sausage. Czech J Food Sci. 2019;37(5):366-73. https://doi.org/10.17221/57/2018-CJFS

22. Empower 3 software, Waters Corporation, Milford, MA, USA; 2017.

23. ISO 1442:2000. Meat and meat products - Determination of moisture content (reference method). Vilnius, Lithuania: Lithuanian Department for Standardization; 2000 (in Lithuanian). 
24. ISO 2917:2002. Meat and meat products - Measurement of pH-Reference method. Geneva, Switzerland: International Organization for Standardization (ISO); 2002.

25. Takao T, Kitakani F, Watanabe N, Yagi A, Sakata K. A simple screening method for antioxidants and isolation of several antioxidants produced by marine bacteria from fish and shellfish. Biosci Biotech Biochem. 1994;58(10):1780-3.

https://doi.org/10.1271/bbb.58.1780

26. Kumarasamy Y, Byres M, Cox PJ, Jaspars M, Nahar L, Sarker SD. Screening seeds of some Scottish plants for free-radical scavenging activity. Phytother Res. 2007;21(7):615-21. https://doi.org/10.1002/ptr.2129

27. ISO 660:2009. Animal and vegetable fats and oils - Determination of acid value and acidity. Geneva, Switzerland: International Organization for Standardization (ISO); 2009.

28. ISO 3960:2017. Animal and vegetable fats and oils - Determination of peroxide value - lodometric (visual) endpoint determination. Geneva, Switzerland: International Organization for Standardization (ISO); 2017.

29. ISO 7218:2007. Microbiology of food and animal feeding stuffs - General requirements and guidance for microbiological examinations. Geneva, Switzerland: International Organization for Standardization (ISO); 2007.

30. Ben-Gigirey B, Vieites Baptista de Sousa JM, Villa TG, Barros-Velázquez J. Characterization of biogenic amine-producing Stenotrophomonas maltophilia strains isolated from white muscle of fresh and frozen albacore tuna. Int J Food Microbiol. 2000;57(1-2):19-31.

https://doi.org/10.1016/S0168-1605(00)00240-3

31. CIE recommendations on uniform color spaces, color-difference equations, and metric color terms. Color Res Appl. 1977;2(1):5-6.

https://doi.org/10.1002/j.1520-6378.1977.tb00102.x

32. SAS ${ }^{\circledR}$ Studio, v. 5.1, User's guide, SAS Institute Inc, Cary, NC, USA; 2019. Available from: http://documentation.sas.com/ api/docsets/webeditorug/5.1/content/webeditorug.pdf?local $9 \mathrm{e}=\mathrm{en}$.

33. Xu Y, Xia W, Yang F, Kim JM, Nie X. Effect of fermentation temperature on the microbial and physicochemical properties of silver carp sausages inoculated with Pediococcus pentosaceus. Food Chem. 2010;118(3):512-8.

https://doi.org/10.1016/j.foodchem.2009.05.008

34. Naila A, Flint S, Fletcher G, Bremer P, Meerdink G. Control of biogenic amines in food-existing and emerging approaches. J Food Sci. 2010;75(7):R139-50.

https://doi.org/10.1111/j.1750-3841.2010.01774.x

35. Guyot JP, Calderon M, Morlon-Guyot J. Effect of pH control on lactic acid fermentation of starch by Lactobacillus manihotivorans LMG 18010'. J Appl Microbiol. 2000;88(1):176-82. https://doi.org/10.1046/j.1365-2672.2000.00953.x

36. Berardo A, Devreese B, De Maere H, Stavropoulou DA, Van Royen G, Leroy F, De Smet S. Actin proteolysis during ripening of dry fermented sausages at different $\mathrm{pH}$ values. Food Chem. 2017;221:1322-32.

https://doi.org/10.1016/j.foodchem.2016.11.023

37. Kameník J, Steinhauserová P, Saláková A, Pavlík Z, Bořilová $G$, Steinhauser L,Ruprich J. Influence of various pork fat types on the ripening and characteristics of dry fermented sausage. Czech J Food Sci. 2013;31(5):419-31.

38. Malterud KE, Bremnes TE, Faegri A, Moe T, Sandanger Dugstad EK, Anthonsen T, Henriksen LM. Flavonoids from the wood of Salix caprea as inhibitors of wood-destroying fungi. J Nat Prod. 1985;48(4):559-63. https://doi.org/10.1021/np50040a007

39. Pausler MG, Ayer WA, Hiratsuka Y. Benzoic acid, salicylic acid, and the role of black galls on aspen in protection against decay. Can J Forest Res. 1995;25(9):1479-83.

https://doi.org/10.1139/x95-160

40. Ojha KS, Kerry JP, Duffy G, Beresford T, Tiwari BK. Technological advances for enhancing quality and safety of fermented meat products. Trends Food Sci Tech. 2015;44(1):105-16. https://doi.org/10.1016/j.tifs.2015.03.010

41. Kim JH, Lee HJ, Park Y, Ra KS, Shin KS, Yu KW, et al. Mucilage removal from cactus cladodes (Opuntia humifusa Raf.) by enzymatic treatment to improve extraction efficiency and radical scavenging activity. LWT - Food Sci Technol. 2013; 51(1):337-42.

https://doi.org/10.1016/j.lwt.2012.10.009

42. Sroka Z, Cisowski W. Hydrogen peroxide scavenging, antioxidant and anti-radical activity of some phenolic acids. Food Chem Toxicol. 2003;41(6):753-8. https://doi.org/10.1016/S0278-6915(02)00329-0

43. Lorenzo JM, Munekata PES, Domínguez R. Role of autochthonous starter cultures in the reduction of biogenic amines in traditional meat products. Curr Opin Food Sci. 2017;14:61-5.

https://doi.org/10.1016/j.cofs.2017.01.009

44. Falowo AB, Fayemi PO, Muchenje V. Natural antioxidants against lipid-protein oxidative deterioration in meat and meat products: A review. Food Res Int. 2014;64:171-81. https://doi.org/10.1016/j.foodres.2014.06.022

45. Semenova AA, Kuznjecova TG, Nasonova VV. Possibilities of application of dihydroquercetin for stabilising quality of sausages produced from mechanically deboned polutry meat. Tehnol mesa. 2008;49(3-4):113-6 (in Serbian).

46. Bakalivanova T, Kaloyanov N. Effect of taxifolin, rosemary and synthetic antioxidants treatment on the poultry meat lipid peroxidation. Cr Acad Bulg Sci. 2012;65(2):161-8.

47. Essid I, Hassouna M. Effect of inoculation of selected Staphylococcus xylosus and Lactobacillus plantarum strains on biochemical, microbiological and textural characteristics of a Tunisian dry fermented sausage. Food Control. 2013;32(2):707-14.

https://doi.org/10.1016/j.foodcont.2013.02.003 